\title{
RELATIONSHIP BETWEEN ORGANIZATIONAL CLIMATE AND JOB SATISFACTION:: AN EXAMINATION OF CUSTOMS OFFICERS IN SRI LANKA
}

\section{ALUTH GEDERA CHANDANI SENEVIRATNA}




\section{RELATIONSHIP BETWEEN ORGANIZATIONAL CLIMATE AND JOB SATISFACTION: AN EXAMINATION OF CUSTOMS OFFICERS IN SRI LANKA}

\section{BY}

\section{ALUTH GEDERA CHANDANI SENEVIRATNA}

(Registration Number 5266FM2010117)

A research submitted to the University of Sri Jayewardenepura in partial fulfillment of the requirements for the Degree of Master of Business Administration on 31.01.2013 


\section{Declaration}

The work described in this research was carried out by me under the supervision of Dr. Aruna S. Gamage and a report on this has not been submitted in whole or in part to any university or any other institution for another Degree/Diploma

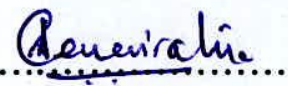

A.G.C. Seneviratna

5266FM2010117

Date : 31.01 .2013 
"I certify that the above statements made by the candidate is true and that this research is suitable for submission to the University for the purpose of evaluation"
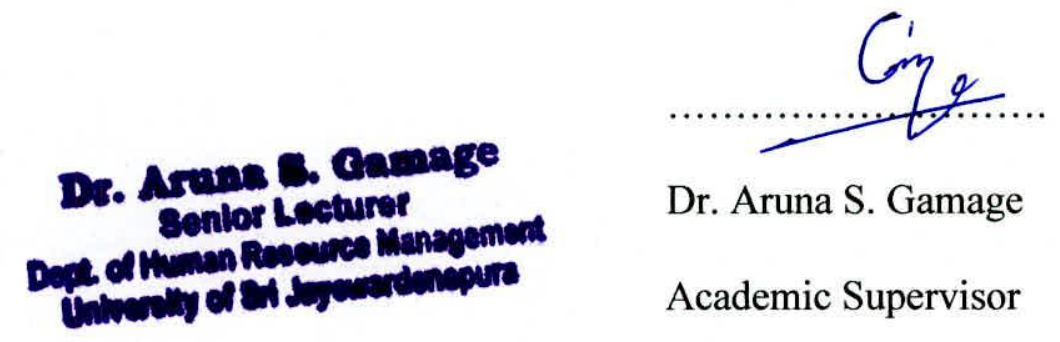

Dr. Aruna S. Gamage

Academic Supervisor

Date : 31.01 .2013 


\section{Acknowledgement}

Successful completion of this research would have not been possible without the support and cooperation of others.

I express my deepest gratitude to Dr. Aruna S.Gamage, my academic supervisor who has been there to share his experience and guidance, comments and his valuable time over the period of my research for the successful completion.

Sincerely I thank the management of Sri Lanka Customs and the Officers of Customs for the fullest support and cooperation given during my study. I also like to thank the officers at the Special Task and Vigilance Division (Passenger Baggage Examination Unit), Orugodawatta for the on-going support and for being flexible with my work schedule.

My warmest thank goes to Nilanthi, Manoja, Buddeen, Sanjeev, Dilini and Nirmala for the comradeship and utilization of their valuable time for supporting me to complete this research successfully.

My sincere thank goes to the academic and non academic staff of the M.Sc. Unit at the University of Sri Jayewardenepura for their kind cooperation and support.

Finally but not least, thank goes to my loving mother Nanda Seneviratna, sisters Manushanthi and Deepani for encouragement given to complete this research 
successfully. Also warmest and big thank to my ever loving son Yehan being sacrificing his life for not being with his mother to share his affectionate and being patient during my study. 
$\begin{array}{lll}2.4 & \text { Leadership style } & 19\end{array}$

2.5 Communication 24

$\begin{array}{lll}2.6 & \text { Supervisory support } & 27\end{array}$

$\begin{array}{lll}2.7 & \text { Job satisfaction } & 29\end{array}$

2.8 Studies in organizational climate and job satisfaction 35

2.9 Hypothesis formulated 42

2.10 Summary 43

CHAPTER 3 - METHODOLOGY

$\begin{array}{lll}3.1 & \text { Introduction } & 44\end{array}$

3.2 Selection of sample 44

$\begin{array}{lll}3.3 & \text { Data collection }\end{array}$

$\begin{array}{lll}3.4 & \text { Reliability and validity }\end{array}$

$\begin{array}{lll}3.5 & \text { Conceptualization } & 46\end{array}$

3.6 Conceptual frame work 53

3.7 Operationalization $\quad 56$

$\begin{array}{lll}3.8 & \text { Data Analysis } & 57\end{array}$

3.9 Summary $\quad 59$

CHAPTER 4 - DATA ANALYSIS AND PRESENTATION

$\begin{array}{lll}4.1 & \text { Introduction } & 60\end{array}$

$\begin{array}{lll}4.2 & \text { Demographic data } & 60\end{array}$ 
4.3 Measures of independent variables and

dependent variable

4.4 Correlation between independent variables and the $\begin{array}{ll}\text { dependent variable } & 66\end{array}$

$\begin{array}{lll}4.5 & \text { Regression analysis of variables } & 74\end{array}$

4.6 Demographic data correlation 75

$\begin{array}{lll}4.7 & \text { Summary } & 75\end{array}$

CHAPTER 5 - DISCUSSION

$\begin{array}{lll}5.1 & \text { Introduction } & 77\end{array}$

$\begin{array}{lll}5.2 & \text { Discussion } & 77\end{array}$

$\begin{array}{lll}5.2 & \text { Summary } & 80\end{array}$

CHAPTER 6-SUMMARY AND CONCLUSION

6.1 summary and conclusion $\quad 81$

$\begin{array}{ll}\text { REFERENCES } & 84\end{array}$

APPENDIX

Questionnaire 


\section{LIST OF TABLES}

Table 1 Summary of data collection 45

Table 2 Questionnaire summary 55

Table 3 Concepts and variable summary 56

Table 4 Distribution of Gender in data $\quad 59$

Table 5 Distribution of Designation in data 60

Table 6 Distribution of Educational qualification in data 60

$\begin{array}{lll}\text { Table } 7 & \text { Distribution of Experience in data }\end{array}$

Table $8 \quad$ Distribution of Age in data 61

Table $9 \quad$ KMO Measure of variable 61

Table $10 \quad$ Cronbach's alpha values of variables 62

Table 11 Correlation analysis of organizational structure and job satisfaction variables

Table 12 Correlation analysis of organizational structure and job satisfaction indexes

Table 13 Correlation analysis of leadership style and job satisfaction variables

Table 14 Correlation analysis of leadership style and job satisfaction indexes

Table 15 Correlation analysis of communication and job satisfaction variables

Table 16 Correlation analysis of communication and job satisfaction indexes

Table 17 Correlation analysis of supervisory support and job satisfaction variables 
Table 18 Correlation analysis of supervisory support and job satisfaction indexes

Table 19 Regression analysis of variables 73

Table 20 Demographic data correlation

74 


\section{LIST OF FIGURES}

Figure 1 Hierarchy of Sri Lanka Customs 06

Figure 2(a) Conceptual frame work 53

Figure2(b) Conceptual frame work 55 


\title{
RELATIONSHIP BETWEEN ORGANIZATIONAL CLIMATE AND JOB SATISFACTION: AN EXAMINATION OF CUSTOMS OFFICERS IN SRI LANKA
}

\author{
A.G.C. Seneviratna
}

\begin{abstract}
The purpose of this research is to examine the relationship between organizational climate and job satisfaction of Customs Officers in Sri Lanka. The study was done focusing to selected variables in organizational climate and job satisfaction. It entails a closer look at examining the relationship between the four identified variables, i.e. organizational structure, leadership style, communication and supervisory support to the job satisfaction. A total number of 114 Customs Officers were selected who represents the total population of the officers. The researcher personally administered the distribution of the questionnaire. Data were collected during the period from $25^{\text {th }}$ November to $31^{\text {st }}$ December 2012.
\end{abstract}

The results from this analysis confirm the research questions that organizational climate variables such as organizational structure, leadership style, communication and supervisory support are positively significantly related to job satisfaction of Customs Officers in Sri Lanka. 


\section{CHAPTER 1}

\section{INTRODUCTION}

\subsection{Introduction to the study}

Asian economies have given priority for public sector management as they are moving towards professional management in government. The government has ventured its political stability on delivering significant and noticeable improvements to public services. Relationship between the outputs and the inputs of any organization measures the efficiency of the organization. One that produces the maximum possible outputs given its inputs, or one that produces a certain level of outputs with the minimum amount of inputs would be an efficient organization.

Most of the countries have realized the importance of trade to achieving sustainable economic growth more than ever. The concept of organizational climate has been of considerable importance to the field of organizational development. Climate looks at the current connection between individuals, groups, and performance and it lends itself more easily to change by management in their attempt to influence the behavior of their subordinates. It is a feature of the organization experienced by employees on a daily basis (McKenna, 2000). Schneider, (2008) described, climate as an experientially based description of the work environment, and more specifically, employee's perception of the formal and informal policies and practices and procedures in their organization. According to Kaczta and Kirk (1978) organizational climate is a set of attributes, which can be perceived within a particular organization, department or unit. Organizational 
climate has a great significance of human relations and resources in all levels. Therefore, it is a core circle of human environment in which employees of an organization works. Favourable climate is directly impact on the organizational growth. Organizational climate has a major influence on motivation, productivity and job satisfaction. Organizational climate deals with inter-perceptions of employees toward their own organization, hence different organizations with different practices and procedures will therefore have different climate construct. In this study organizational climate has been defined as relatively enduring quality of the internal environment of an organization which experienced, influenced, attitudes of the employees of the organization. Job satisfaction is important in everyday life. Organizations have impact on employees' work and their work in organizations. Since much of time employees spent in the organization, the environment surrounding the individual has important costs for him/her personally and professionally. Job satisfaction means the contentment of the employees because of their jobs. It is the personal evaluation of the job conditions (the job itself, the attitude of the administration etc.) or the consequences or (wages, occupational security etc) acquired from the job (Fletcher and Williams, 2006). According to Fajana (1996) Job satisfaction is very important in an organization because if employees are not satisfied, their work performance, productivity, commitment as well as the inter-personal relationships among the management and their subordinates tend to be lowered. Job satisfaction should be given more importance than other behavioural variables because it has direct link with organizational outcomes (Schneider, 1990). 
As a result of economic liberalization in 1977, many of the public sector organizations tended to decline due to huge competition and miss-management. Private sector emerged as dynamic sector and driving force of the overall economy of the country. Historically, the public sector employees take home nothing from their profession except remuneration. Employees are pressed by the rules, regulations and legislations. Moreover, government organizations practices bureaucratic managerial style. Due to these facts job satisfaction of the public sector employees may reduce. Therefore, it a necessary to have a better relationship of the organizational climate factors to job satisfaction factors. Sri Lanka Customs is also one of the most important departments in this country which collects the revenue. To have a better environment for the officers of the department, it is essential to identify the factors which will cause dissatisfaction. With this intention the research was brought out to observe the factors that would affect the job satisfaction of Customs Officers in Sri Lanka Customs.

\subsection{Overview of the selected organization}

All over the world, entire nation are occupied with some work. Some of our work is interesting and some are monotonous and less attractive. Comparison of work depends on the personality. Though we are occupied with work, it may not satisfied and meaningful to us.

When we consider an organization, jobs are categorized and satisfaction of job varying to each other. Satisfaction depends on the internal and external work milieu. Employees are one of the main assets of any organization. 